\section{National Physical Laboratory Abstracts}

AFTER the publication of the volume of "Collected Researches" of the National Physical Laboratory at present in the press, that quarto publication will cease and will be replaced by an annual octavo pamphlet entitled "Abstracts of Papers", the first issue of which, for the year 1936, has already appeared. It extends to 65 pages, 61 of which are devoted to 140 abstracts and the rest to author and subject indexes. The title of each abstract is in Clarendon type and that of the publication in which the complete paper is to be found in italics with specification of year, volume and page. The abstracts themselves generally give the object and method of the investigation concerned in outline and the net results in detail, so that a large amount of valuable information is condensed into a small space. They are grouped under subjects. The present issue is published at 18 . by H.M. Stationery Office.

\section{Esperanto for Scientific Papers and Abstracts}

ThE "Universala Esperanto-Kongreso" is to take place this year at University College, London, on July 30-August 6. A recent article by Dr. D. R. Duncan, published in the Scientific Worker, directs attention to the great potential value of Esperanto as a means of intercommunication between men of science. Being "intelligible to any educated European" without previous study, it is eminently suitable for scientific abstracts in cases where the original paper was published in a language little known outside its own country. Reports consisting largely of tables such as the "International Critical Tables" might well, it is suggested, use Esperanto instead of numerous parallel columns in different languages. Esperanto is, it appears, much used in Japan for scientific papers. A few journals outside Japan give Esperanto summaries at the end of papers published in the journal's own language, for example, the Bull. Soc. Française des Electriciens, the Phare Médical and the Revista da Sociedade de Geografia do Rio de Janeiro.

\section{Society for Extending the Rothamsted Experiments}

His Grace the Duke of Devonshire has consented to accept the chairmanship of the Incorporated Society for Extending the Rothamsted Experiments which had been held by his late father since the inception of the Society in 1904. The vice-chairmen are the Earl of Radnor and Lord Clinton. The purpose of the Society is to foster the development of the work carried out by the Rothamsted Experimental Station: the last important effort was to raise the funds for the purchase of the agricultural part of the Rothamsted Estate, which was success. fully achieved in 1934, and its next effort will be in connexion with the centenary of the foundation of the Rothamsted Experimental Station which falls due in 1943.

\section{Growth of a Sunspot}

BETwEEN May 22 and 24, a large group of sunspots suddenly appeared near the central meridian and became visible to the naked eye. Measures of area taken from the Greenwich photographs show the following rapid increase in size of the spot group, which began as two or three tiny spots. The areas are corrected for foreshortening and are expressed in millionths of the sun's hemisphere.

\begin{tabular}{|c|c|}
\hline May & $22 \cdot 4$ \\
\hline , & $23 \cdot 3$ \\
\hline & $24 \cdot 3$ \\
\hline & $25 \cdot 4$ \\
\hline & $26 \cdot 3$ \\
\hline
\end{tabular}

$\begin{array}{rl}10 & \text { millionths } \\ 210 & , \\ 1060 & , \\ 1200 & , \\ 1390 & ", \\ 1570 & ,\end{array}$

Since the average group of this size takes about 8-10 days to develop fully, the very great increase in area during the first 48 hours suggested that the group would be unusually large, exceeding perhaps 2500 millionths. The maximum size appears, however, to have been reached about May 27 or 28, the group passing out of view at the western limb on May 30. These sunspots, in about latitude $8^{\circ}$ north and longitude $12^{\circ}$, offered several points for study with an ordinary telescope. There was, for example, a marked drift equatorwards of the leader spot amounting to $3^{\circ}$ or about $37,000 \mathrm{~km}$. between May 24 and 27. The changes in structure between May 23 and 24 were also considerable. During the initial development of the group, the accompanying hydrogen flocculi seen spectroscopically in $H \alpha$ (and at times in $H \beta$ ) were persistently of enhanced intensity, although no outstanding short-lived eruptions were observed at Greenwich. The time of central meridian passage of the group was May $23 \cdot 8$, and it will return to the central meridian on June 20 , unless by then the spots have dispersed.

\section{Announcements}

WE regret to announce the death of Dr. J. W. Mellor, C.B.E., F.R.S., author of "A Comprehensive Treatise on Inorganic and Theoretical Chemistry", on May 24, aged sixty-eight years; and of Prof. W. Stroud, Cavendish professor of physics in the University of Leeds in 1885-1909, director of Barr and Stroud, Ltd., Glasgow, on May 27, aged seventy. eight years.

Sir Frank Smith, secretary of the Department of Scientific and Industrial Research, has been elected an honorary fellow of the Institute of Physics. This, the highest distinction the Institute can confer, is reserved for those whom it especially desires to honour for exceptionally important services in connexion with physics or a science allied thereto; there are only seven other honorary fellows. Sir Frank Smith was a founder fellow of the Institute, and did much to help establish it on the sound basis which has assisted so much in its rapid development.

Mr. A. H. R. FedDen has been elected president of the Royal Aeronautical Society for the year 1938-39.

THe annual inspection of the field plots and laboratories of the Rothamsted Experimental Station 
will be held on June 29, beginning at 11.15 a.m. Further information can be obtained from the Secretary, Rothamsted Experimental Station, Harpenden, Herts.

WE are informed that $\mathrm{J}$. Wadsworth has resigned the directorship of Apia Observatory, Western Samoa, and expects to leave Samoa shortly.

Major-GeneraI C. H. Foulkes writes: "It has been suggested that my review in NATURE of May 21 of Prof. Kendall's book 'Breathe Freely' might give the impression that the author is 'anti-A.R.P.'. This was very far from my intention, and in view of recent events in Spain and China, it need scarcely be said that no reasonable person could adopt such an attitude."

To encourage the reading of papers by students of fuel technology, the Council of the Institute of Fuel has decided to make an annual reward of a medal, together with a prize consisting of books and/or instruments to the value of $£ 5$ for a paper submitted by a student member of the Institute or by any student less than twenty-five years old of a university or technical college in the United Kingdom. Further particulars can be obtained from the Secretary, Institute of Fuel, 53 Victoria Street, London, S.W.1.

THE twenty-seventh annual meeting of the Oxford Ophthalmological Congress will be held at Keble College on July 6-9. Further information can be obtained from the honorary secretary, Dr. F. A. Anderson, 12 St. John's Hill, Shrewsbury.

THE twenty-fourth annual conference of the National Association for the Prevention of Tuber. culosis will be held in the Great Hall of the British Medical Association House, Tavistock Square, W.C.1, on June 30-July 2.

Ar the International Congress Against Rheumatism recently held at Oxford, Prof. Ralph Pemberton of Philadelphia was elected president of the International League Against Rheumatism in succession to Dr. R. Fortescue Fox. The next Congress is to be held in New York in 1940.

ThE Jessie Macgregor Prize in Medical Science will be awarded next July for the best record of original work on the science of medicine. The work may be published or unpublished, but must not have been published more than three years earlier than July 1938. The value of the prize is about $£ 50$, and it is open to medical women graduates of the University of Edinburgh. Applications should be made to the Convener of Trustees, Royal College of Physicians, Edinburgh, not later than June 30.

Dr. Rudolf Kreutz, of Cologne, has been awarded the Sudhoff Medal by the German Society of the History of Medicine.
Dr. Herbert Hoover, the former president of the United States, has been given an honorary doctorate of the Technical University of Vienna.

Dr. CarL Landsteiner, of the Rockefeller Institure, New York, has been awarded the Cameron Prize of the University of Edinburgh, for his work on blood grouping and blood transfusion.

The John Phillips Memorial Medal of the American College of Physicians was recently awarded to Dr. Harry Goldblatt, professor of experimental pathology, Western Reserve University School of Medicine, Cleveland, for his work on the production of experimental hypertension in animals.

A monument to the late Mme. Curie was unveiled in Roosevelt Park, Raritan Township, New Jersey, on April 24, the seventieth anniversary of her birth.

As Argentine Institute of Nutrition attached to the Ministry of Foreign Relations has recently been founded at Buenos Aires.

THE third International Congress for the Study of Goitre will be held on September 13-14 at Washington, when the following subjects will be discussed: (1) endemic goitre, cretinism and myxodema; (2) thyroid gland and metabolism, nutrition and endocrine glands; (3) hyperthyroidism. Further information can be obtained from Dr. Allen Graham, 2020 East 92nd Street, Cleveland, Ohio, U.S.A.

THE sixteenth International Congress of Physiology will be held at Zurich on August 14-18 under the presidency of Prof. W. R. Hess. It will consist of six sections devoted respectively to general and comparative physiology, biophysics, biochemistry, applied physiology (work, sport and aviation), psychophysiology and pharmacology. Further information can be obtained from Prof. E. Rottlin, Sonnenweg 6, Basel, Switzerland.

A Note upon the "Scialyscope", which provides a means by which surgical operations may be viewed by a number of students in a room adjacent to the operation theatre, was published in NATURE of April 30, p. 780. Mr. G. Davidson, director of Technical Lights and Equipment, Ltd., 9-10 Bentinck Mews, Marylebone Lane, London, W.1, sends us a copy of a booklet compiled when the instrument was originally invented, as well as copies of illustrated French leaflets and a booklet showing installations of it at different hospitals. Further information can be obtained from that firm.

Erratum. In Nature of May 28, p. 980, paragraph entitled "Condensation on Board Ship", line 2, for “J. S. Duly" read "S. J. Duly". 